\title{
The Effect of Conceptual Metaphors on Learning Idioms by L2 Learners
}

\author{
Elham Rahmani Samani \\ Department of English Language, Faculty of Letters \& Humanities \\ Najaf Abad Branch, Islamic Azad University, Esfahan, Iran \\ E-mail: rahmani.535@hotmail.com \\ Mahmood Hashemian, Ph.D. \\ Department of English Language, Faculty of Letters \& Humanities \\ Shahrekord University, Iran \\ Tel: 98-318-442-2517_E-mail: m72h@hotmail.com, hashemian-m@lit.sku.ac.ir
}

Received: December 2, 2011

Accepted: January 2, 2012 Published: February 1, 2012

doi:10.5539/ijel.v2n1p249

URL: http://dx.doi.org/10.5539/ijel.v2n1p249

\begin{abstract}
This study examined the effect of conceptual metaphors on learning idioms by L2 learners. Seventy juniors participated in this study. They were grouped into two: Group 1 as the experimental group and Group 2 as the control group. Group $1(n=40)$ learned the idioms by conceptual metaphors and Group $2(n=30)$ by traditional methods. The participants were given a pretest in order to check the comprehension and production of idioms, metaphors, and conceptual metaphors. After the pretest, the idioms were instructed to both groups. The first group received conceptual metaphor instruction and the second group the traditional methods. The idiom instruction lasted for one semester. Then, the posttest was given to the participants. Result showed that conceptual metaphors had a significant effect on learning idioms by the L2 participants (Group 1). Results also pointed to the fact that the effect of conceptual metaphors on learning idioms was more than that of traditional methods. Group 2 could learn idioms, but failed to draw the meaning of idioms because their metaphorical awareness had not developed.
\end{abstract}

Keywords: Idioms, Metaphor, Conceptual metaphors, Source domain, Target domain

\section{Introduction}

Idioms have a considerable role in an L2. It is difficult for L2 learners to learn all idioms used in the real situation of an L2. As the English language is rich in idioms, learning them in an L2 constitutes the soul of the language (Elkilic, 2008). Learning idioms helps L2 learners for better communication as well as learning in an L2 culture and society. Mastery of appropriate use of idiomatic expressions is a part of important L2 learning (Stight, 1979). Cain, Oakhill, and Lemmon (2005) state that "an idiom is figurative expression that usually can be interpreted literally but that takes a nonliteral meaning when used in a specific context" (p. 66).

Metaphor is an important means of expression in human languages, used in both spoken and written discourse. Kövecses and Szabó (1996) and Kövecses (2002) suggested that a major pitfall in the traditional view of idioms is that linguistic meaning is divorced from the human conceptual system and the encyclopedic knowledge that speakers of a language share.

Being independent of the idioms from any conceptual system and isolation of them from each other at the conceptual level is one of the major stumbling blocks in understanding the nature of idioms as well as teaching and learning of idioms in an L2 context (Kövecses, 2002).

Traditionally, metaphor was viewed as a matter of language, as a set of extraordinary, or figurative linguistic expressions whose meaning was reducible to some set of literal propositions. Recently, however, some scholars (e.g., Lakoff \& Johnson, 1980) have begun to dig deeper into the topic, investigating the possibility that metaphor is not only a form of speech, but also more fundamentally a form of thought, having basic epistemological 
functions. Metaphor is a way of explaining, describing, and evaluating ideas to understand and communicate abstract ideas in our everyday activities.

The first linguists who gave crucial insights into the cognitive theory of metaphor are Lakoff and Johnson (1980) in their seminal study Metaphors We Live By. They found out that many verbal metaphors systematically reflect conceptual metaphors, but do not necessarily have the same form as these conceptual metaphors. That is, "what she said left a bad taste in my mouth" and "I just can't swallow that claim"both reflect the underlying conceptual metaphor IDEAS ARE FOOD, with neither the word ideas nor the word food occurring in the metaphorical sentences. Later in 1986, Kövecses demonstrated in Metaphors of Anger, Pride and Love that verbal expressions and idioms about emotions could be traced back to a limited number of conceptual metaphors. The term conceptual metaphor is used to refer to a connection between two semantic areas at the level of thought, such as the metaphorical connection that seems to exist between anger and fire for speakers of many languages (Lakoff, 1987).

According to the cognitive linguistic view, metaphor is not a figure of speech restricted to literature or poetics, but it is a factor that shapes the way we think, act, and interact. It suggests that the meanings of many idioms are not arbitrary; rather, they are motivated by three mechanisms: metaphor, metonymy, and conventional knowledge (Kövecses, 2002).

$\mathrm{Li}$ (2010) stated that three aspects should be considered for applying conceptual metaphors in idioms teaching. Firstly, L2 teachers' metaphorical competence should be improved. Secondly, L2 learners' metaphorical awareness should be cultivated. Finally, relevant cultural background should be inputted.

The general meaning of many idioms (i.e., what concepts they are about) remains completely unmotivated, unless we take into account the interplay between meaning and our conceptual system as comprised by conceptual metaphors to a large extent. It is claimed that the meaning of many (though not all) idioms, depends on, and is inseparable from, the (metaphorical) conceptual system. The lack of awareness of metaphorical concepts often leads L2 learners not to understand and not to use metaphors in natural communication. It is necessary for L2 teachers and learners to be familiar with the conceptual systems of an L2 and people who speak that language because familiarization with the conceptual system of an L2 is made possible with the learning of conceptual metaphors of that L2 (Lakoff \& Johnson, 1980). According to Kövecses (2002), a good way to attain the metaphorical concepts in an L2 is to learn idiomatic expressions. The present study investigated the effect of conceptual metaphors on learning idioms by L2 learners. In addition, it examined whether conceptual metaphors facilitated learning idioms or not. Finally, it examined whether the effect of conceptual metaphors on learning idioms was more than that of traditional methods.

\section{Method}

\subsection{Participants}

The participants, selected through random sampling, consisted of 70 intermediate L2 learners at Islamic Azad University of Khorasgan and Shahrekord University. All were junior students, aged between 19 to 25, who were majoring in English Translation. They took the course "The Application of Metaphorical Expressions in Translation." They were classified into two groups by the Oxford Placement Test (OPT, Allan, 2004): Group 1 as the experimental group and Group 2 as the control group, the rationale of which was to have homogenous L2 learners in each group. Group $1(n=40)$ learned the idioms by conceptual metaphors and Group $2(n=30$ traditional methods.

\subsection{Materials}

The first test was the OPT test. It was used to assess the juniors' degree of homogeneity prior to the study. This test consists of 100 multiple-choice items, which was used to select the intermediate-level L2 learners at Islamic Azad University of Khorasgan and Shahrekord University. According to the scoring guidelines by Allen (2004), the scores among 60-75 were considered as the intermediate level.

The second test was a pretest in the form of an objective test. It was designed to appraise the juniors' idioms, metaphors, and conceptual metaphors knowledge before the treatment. It was piloted on eight participants similar to the main participants of the study to check the instructions, timing, and scoring procedure. As a result of the pilot study, the reliability of the test was computed to be .89 . In addition, the validity of the test was investigated by the expert judgments, including one professor of TEFL and two experienced L2 teachers. By investigating the test specifications like test method, scoring matrix, choice distribution, and selections of items, the validity of the idiom test was confirmed. The test was developed by the present researchers and consisted of 180 multiple-choice items. The participations answered them in about 120 minutes. 
The third test was a posttest in the form of an objective test in order to see whether the application of this test and the instruction of the participants had any effects on metaphoric awareness and the success of learning and interpreting idioms, metaphors, and conceptual metaphors. In fact, the posttest was similar to as the pretest.

One of the books selected for instruction was Idiom Organiser (Wright, 1999). The rational for choosing this book was to expose the juniors to a number of L2 conceptual metaphors of the English language, out of which were born some 206 metaphors and idioms. The conceptual metaphors included in this book are: TIME Is MONEY, BUSINESS

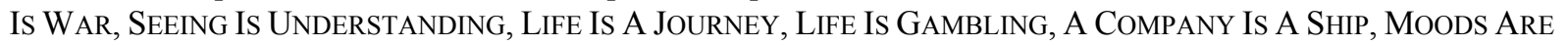
Weather, The Office Is A Battlefield, A Project Is A Race, Economics Is Flying, Organizations Are GARDENS, and PEOPLE ARE LIQUid.

\subsection{Procedure}

As mentioned before, seventy juniors took part in this study who took the course of "The Application of Metaphorical Expressions in Translation." The course met 90 minutes, once a week, for 16 consecutive weeks. The participants were divided into two groups, comprising both sexes. Prior to the administrating of the study, the juniors were tested for their homogeneity. They were tested via a multiple-choice proficiency test (i.e., the OPT). Based on the OPT scores, 70 juniors were selected from among 87 learners. The results showed the homogeneity of the juniors who were classified into two groups. In addition, they were given a pretest in order to check the comprehension and the production of idioms, metaphors, and conceptual metaphors. The test included figurative language, such as idioms, metaphors, and conceptual metaphors.

After the pretest, the idioms were instructed to both groups of the study. The first group was taught via the conceptual metaphor instruction and the second group via the traditional instruction. The idioms instruction lasted one semester for both groups. The instruction is explained below:

\subsubsection{Instruction of Idioms by Conceptual Metaphors}

As for the instruction of metaphorical language, they were initially given some idea of what conceptual metaphors are, and how it is possible to generate innumerable idioms out of such conceptual metaphors. To give some idea of what it could mean for a concept to be metaphorical and for such a concept to structure an everyday activity, the researchers exemplified with the concept ARGUMENT and the conceptual metaphor ARGUMENT IS WAR. This metaphor is reflected in English by a wide variety of expressions:

\section{ARgument Is Was Metaphor}

Your claims are indefensible.

He attacked every weak point in my argument.

His criticisms were right on target.

I demolished his argument.

I've never won an argument with him.

You disagree? Okay, shoot!

If you use that strategy, he'll wipe you out.

He shot down all of my arguments.

The juniors were reminded that we do not just talk about "arguments" in terms of "wars." We can actually win or lose "arguments." We see the person we are arguing with as an opponent. We attack his positions and defend our own. We gain and lose ground. We plan and use strategies. If we find a position indefensible, we can abandon it and take a new line of attack. Many of the things we do in "arguing" are partially structured by the concept of "war." Though there is no physical battle, there is a verbal battle, and the structure of an "argument" (e.g., attack, defense, counter-attack, etc.) reflects this. It is in this sense that the ARGUMENT IS WAR metaphor is one that we live by in English; it structures the action we perform in "arguing." It is not that "arguments" are a subspecies of "wars." "Arguments" and "wars" are different kinds of things-verbal discourse and armed conflict-and the actions performed are different kinds of actions. However, "arguments" are partially structured, understood, performed, and talked about in terms of "wars." The concept, the activity, the language are metaphorically structured. Moreover, this is the ordinary way of having an argument and talking about one. This is an example of what it means for a metaphorical concept, namely, ARGUMENT IS WAR, to structure (at least in part) what we do and how we understand what we are doing when we argue. It is not that "arguments" are a subspecies of "wars." "Arguments" and "wars" are different kinds of things, and the actions performed are different kinds of actions. Nevertheless, "argument" is partially structured, understood, performed, and talked about in terms of "war." The 
concept is metaphorically structured, the activity is metaphorically structured, and, consequently, the language is metaphorically structured. Moreover, this is the ordinary way of having an "argument" and talking about one (Lakoff \& Johnson, 1980).

The above was an introduction given to the juniors prior to exposing them to the conceptual metaphors, metaphors, and idiomatic expressions of the English language. After the juniors had been exposed to the conceptual metaphors of L2, they comprehended metaphors, idioms, conceptual metaphors better.

As for the book Idioms Organiser (1999, each unit opens with a conceptual metaphor such as BUSINESS IS WAR. Initially, the juniors were reminded that there are two concepts here: One is an abstract concept (here, "business"), and another is a concrete one (here, "war"). It was constantly emphasized that "the essence of metaphor is understanding and experiencing one kind of thing in terms of another" (Lakoff \& Johnson, 1980). Next, the literal meanings of words coming from the concrete concept (here, "war") were examined in various sentences. The juniors were asked to look up the meanings of unfamiliar words in their monolingual dictionaries. Speaking of the domain of "war," there are such literal words like ground, fight, head, sights, flak, force, and march-to name but a few. When it comes to talking about "business," the same words could be used metaphorically. We have expressions like to gain ground, give up without a fight, join forces with, keep one's head down, set one's sights on sth, marching orders, take a lot offlak-to name but a few. After examining the literal meanings of the words from a concrete domain such as "war," the juniors were to study the various metaphors and idioms generated from such domains. They were asked to look up the meanings of the metaphors and idioms in their idiom dictionaries if needed; they were encouraged to fill in the exercises with the appropriate metaphors and idioms; they were asked to write their own sentences using the metaphors and idioms and submit them to the researchers; they were also asked to translate the metaphorical sentences into their L1 if possible, though translation was not a major activity in this research at all; they were asked to engage in communicative activities and apply their own metaphorical sentences; and finally they were asked to write one paragraph for each unit, encouraged to use the idioms in their written discourse, and they had to hand in the paragraphs to the researchers at the end of each session.

\subsubsection{Instruction of Idioms by Traditional Methods}

The researchers used a wide range of techniques for teaching idioms like discussion, definitions, division of idioms into categories, dramatization, drawing, storytelling, games, audio and video activities, and so forth.

Finally, the posttest was administered to see whether the application of the above test and the instruction of the participants had any effects on learning and interpreting idioms, metaphors, and conceptual metaphors.

\section{Results and Discussion}

In order to see the equality of the mean scores of the pretest, the scores obtained from the pretest of both groups were statistically analyzed, using an independent $t$ test. As shown in Table 1, the results from the pretest scores show there is no difference between the means of the performance of Group 1 and Group $2(t=.922, d f=68, \alpha=$ $0.05, p=.380)$. Because $p$ value is more than $\alpha$, there is no difference between the means of the pretest scores of the two groups. So, there was no difference between the performances of the juniors on the means of the pretest scores, and the juniors were considered homogenous prior to the launching of the study:

$<$ Insert Table 1 here>

In order to see if the effect of conceptual metaphors on learning idioms was more than that of the traditional methods, the repeated measures test was used. As shown in Table 2 , the result from the equality of mean scores of Group 1 and Group 2 shows that there is a significant difference between the mean scores of both groups $(\alpha=0.05$, $p=0.00$ ). Because $p$ value is less than $\alpha$, there is a significant difference between the mean scores of both groups and the effect of conceptual metaphors on learning idioms is more than that of traditional methods because the mean scores of the posttest in Group 2 is more than that of Group 1:

$<$ Insert Table 2 here>

As shown in Table 3, the scores of the juniors have changed from the pretest to the posttest $(\alpha=0.05, p=0.00)$. Because $p$ value is less than $\alpha$, the equality of the mean scores in both groups is rejected:

$<$ Insert Table 3 here $>$

In order to see the difference between the pretest and the posttest scores, the scores obtained from the pretest and the posttest exams were statistically analyzed, using two paired samples $t$ tests: one paired samples $t$ test for Group 1 and one paired samples $t$ test for Group 2. As shown in Table 4, the result from the pretest and the posttest scores in Group 1 show that there is a significant difference between the means of performances of Group $1(t=-20.822$, $d f=39, \alpha=0.05, p=0.00)$. Because $p$ value is less than $\alpha$, there is a significant difference between the means of the 
pretest and the posttest scores. There is a significant difference between the performance of Group 1 on the pretest and posttest scores:

$<$ Insert Table 4 here $>$

As depicted in Table 5, the result from the pretest and the posttest scores in Group 2 show that there is a significant difference between the means of performances of Group $2(t=-17.058, d f=29, \alpha=0.05, p=0.00)$. Because $p$ value is less than $\alpha$, there is a significant difference between the means of the pretest and the posttest scores:

$<$ Insert Table 5 here $>$

In fact, there is a significant difference in the mean scores of the posttest for the juniors, and the difference between the pretest and the posttest in Group 1 is more than that of Group 2. As a result, conceptual metaphors facilitated learning of the idioms, and the effect of conceptual metaphors on learning idioms was more than that of the traditional methods.

\section{Conclusion}

The results pointed to the fact that conceptual metaphors had significant effect on learning idioms by the L2 participants because the result from the pretest and posttest scores for the juniors showed that there was a significant difference between the mean of performance of the juniors $(t=-20.822, d f=39, \alpha=0.05, p=0.00)$. Because $p$ value was less than $\alpha$, there was a significant difference between the mean of the pretest and posttest scores. There was a significant difference between the performance of the L2 participants (i.e., Group 1) on the pretest and posttest scores. Therefore, the conceptual metaphors had a significant effect on learning idioms.

The findings of this study are agreement with Li (2010) who illustrated the cognitive motivation of English and Chinese idioms based on the conceptual metaphor theory and found most English and Chinese idioms were motivated by conceptual metaphors in a systematic way, and conceptual metaphors accelerated the teaching and learning of idioms.

In another study by Gibbs, Bogdanovich, Sykes, and Barr (1997), the role of conceptual metaphors in idioms comprehension was examined. What they were interested in was to find whether people quickly accessed conceptual metaphors each time an idiom was encountered in discourse. They found that conceptual metaphors could under some circumstances be quickly accessed during idioms comprehension, and people accessed the appropriate conceptual metaphors when they processed some idioms.

Kömür and Çimen's (2009) findings are in consonance with the result of this study. They found that conceptual metaphors affected teaching idioms in an L2 context. They developed lesson plans, and the lesson plans contained activities that enhanced the L2 learners' metaphorical perceptions in the L2. The results of their study showed that the implementation of these lesson plans enhanced the L2 learners' metaphorical awareness and enabled them to be successful in understanding idioms.

Also, the results pointed to the fact that the effect of conceptual metaphors on learning idioms was more than that of traditional methods. The result from the pretest and posttest scores in Group 2 showed that there was a significant difference between the mean of performance of Group $2(t=-17.058, d f=29, \alpha=0.05, p=0.00)$. Because $p$ value was less than $\alpha$, there was a significant difference between the mean of the pretest and posttest scores, and the result from the pretest and posttest scores in Group 1 showed that there was a significant difference between the mean of performance of Group $1(t=-20.822, d f=39, \alpha=0.05, p=0.00)$. Because $p$ value was less than $\alpha$, there was a significant difference between the mean of the pretest and the posttest scores. The performance of the participants in learning idioms by conceptual metaphors was better than that of the traditional methods because the mean scores of the pretest and posttest in conceptual metaphors was more than that of traditional methods. It shows that conceptual metaphors facilitated learning idioms. The participants who had learned idioms by the conceptual metaphor instruction could keep idioms in their mind better because they were familiar with the literal and metaphorical meaning of the words. Also, the participants who learned idioms by the traditional methods could learn idioms but they failed to draw the meaning of the idioms because their metaphorical awareness was not raised. In addition, they were not aware of this fact that most idioms are products of our conceptual system and are not simply a matter of language.

Most students who are majoring in English Translation and TEFL must take the course "The Application of Metaphorical Expressions in Translation." Unfortunately, most L2teachers do not resort to a good method for teaching idioms. From the teaching point of view, idioms create special problems for L2 teachers. L2 idioms are not taught very well (Granger, 1998; Irujo, 1986). This study helps L2 researchers, syllabus designers, and teachers to apply conceptual metaphors for teaching idioms in the classroom at university as well as in the academic schedule. 
Learning vocabulary, expressions, and idioms presented in an organized fashion is easier than random lists of idioms. Organizing lexis, idioms, and expressions in groups is effective for L2 learners because it facilitates connecting the new items with already familiar ones. Therefore, it is reasonable to introduce L2 learners grouping of words, idioms, and expressions that are made up of familiar items and just a few new ones, and then help them add more expressions to the established groups as they come across later. Idioms can be grouped according to conceptual metaphors, or the source domains they have in common. For example, the expressions used to describe anger can be grouped under headings like ANGER Is HEAT (e.g., He's blowing off steam, He blew up at me or She's funning).

Another implication of this study is that idioms should be grouped according to conceptual metaphors. Therefore, in this way L2 learners can learn idioms better and increase the chance of remembering them longer. The book Idioms Organiser (1999) was chosen for to be taught to the participants. Each unit starts with a conceptual metaphor, and all of the idioms in that unit are related to that conceptual metaphor. In fact, all of the idioms in each unit are grouped according to that conceptual metaphor. In this way, L2 learners were familiar with the literal and idiomatic use of words and kept the words with nonliteral and metaphorical meanings in their minds better.

Boers (1999), Deignan, Gabryś, and Solska (1997), Lazar (1996), and Liu (2008) offer sample activities that aim at raising metaphoric awareness and give L2 learners the opportunity to make cross-linguistic comparisons and express themselves in metaphorical terms. These activities comprise gap-filling exercises, metaphoric themes recognition, activities applicable to both monolingual and multilingual groups, making sentences using idioms, telling stories based on pictures, retelling and add-on stories, idiom notebooks and flashcards, association of idioms with mental images, hypothesizing and learning the origin of the idioms, using idioms dictionaries, playing idiom games, replacing marked expressions with idioms, and completing a story or a paragraph. Cultivating L2 learners' metaphorical awareness can be one of the implications of the study. The present researchers engaged L2 learners in communicative activities (and used some of the abovementioned activities); then, the L2 participants applied their own metaphorical sentences. Next, they wrote one paragraph for each unit and used the idioms in their written discourse. In this way, their metaphorical awareness was boosted.

The most important implication of this study is that L2syllabus designers and curriculum developers can include conceptual metaphors, conceptual metonymy, and conventional knowledge in L2 textbooks as an applicable and suitable method in teaching idioms.

There are three cognitive mechanisms in the motivation of the idioms (i.e., conceptual metaphors, conceptual metonymy, and conventional knowledge). Even though the application of conceptual metaphors in teaching idioms could create a new method for teaching idioms in L2 learners and facilitate idiom learning, but more research is required to investigate the effects of the other mechanisms (i.e., conceptual metonymy and conventional knowledge) on idiom teaching and learning. Because idioms cannot just be motivated by conceptual metaphors, and they need other mechanisms.

The proficiency of L2 learners is one of the important factors in learning idioms. It is hoped that further research can be taken into consideration the levels of L2 learners and examine this study on different proficiency levels. According to Trosborg (1997), L2 learners' ability to figure out the meaning of metaphorical idioms was correlated with their proficiency in an L2. Further researcher can perform this study on different levels of L2 learners, so the effect of the different levels of L2 learners on learning idioms by conceptual metaphor instruction still remains without an answer. Moreover, L2 learners might come up with problems concerning the notion of abstract and concrete in the concepts, but it depends on the level of such L2 learners. Therefore, future researchers can take into account to this matter. Further research can be done on this matter whether L2 learners can use conceptual metaphors automatically when confronting idioms or not. There are three types of conceptual metaphors according to their cognitive function: structural, orientation, and ontological. Further research can be done on these kinds of conceptual metaphor as to how they are related to the motivation of the idioms.

\section{References}

Boers, F. (1999). Learning vocabulary through metaphoric awareness. Études et Travaux, 3, 53-65.

Cain, K., Oakhill, J. \& Lemmon, K. (2005). The relation between children's reading comprehension level and their comprehension of idioms. Journal of Experimental Child Psychology, 90, 65-87. http://dx.doi.org/10.1016/j.jecp.2004.09.003

Deignan, A., Gabryś, D. \& Solska, A. (1997). Teaching English metaphors using cross-linguistic awareness-raising activities. ELT Journal, 51, 352-360. http://dx.doi.org/10.1093/elt/51.4.352 
Elkilic, G. (2008). Turkish students' understanding of transparent and opaque idioms in English in reading as well as speaking. Journal of Language and Linguistic Studies, 4, 27-41.

Gibbs, R. W., Bogdanovich, J. M., Sykes, J. R. \& Barr, D. J. (1997). Metaphor in idiom comprehension. Journal of Memory and Language, 37, 141-154. http://dx.doi.org/10.1006/jmla.1996.2506

Granger, S. (1998). Prefabricated patterns in advanced EFL writing: Collocations and formulae. In A. Cowie (Ed), Phraseology: Analysis and applications. Oxford: Oxford University Press.

Irujo, S. (1986). Don't put your leg in your mouth: Transfer in the acquisition of idioms in a second language. TESOL Quarterly, 20, 287-304. http://dx.doi.org/10.2307/3586545

Kömür, S. \& Çimen, S (2009). Using conceptual metaphors in teaching idioms in L2 context. Muğla Üniversitesi Sosyal Bilimler Enstitüsü Dergisi (ILKE) Güz, 205-221.

Kövecses, Z. (1986). Metaphors of anger, price, and love: A lexical approach to the structure of concepts. Amsterdam and Philadelphia: John Benjamin Publishing Company.

Kövecses, Z. (2002). Metaphor: A practical introduction. Oxford: Oxford University Press.

Kövecses, K. \& Szabó, P. (1996). Idioms: A view from cognitive semantics. Applied Linguistics, 17, 326-355. http://dx.doi.org/10.1093/applin/17.3.326

Lakoff, G. (1987). Women, fire, and dangerous things: What categories reveal about the mind. Chicago: University of Chicago Press.

Lakoff, G. \& Johnson, M. (1980). Metaphors we live by. Chicago: University of Chicago Press.

Lazar, G. (1996). Using figurative language to expand students' vocabulary. ELT Journal, 50, 43-51. http://dx.doi.org/10.1093/elt/50.1.43

Li, X. (2010). Conceptual metaphor theory and teaching of English and Chinese idioms. Journal of Language Teaching and Research, 1, 206-210. http://dx.doi.org/10.4304/jttr.1.3.206-210

Liu, D. (2008). Idioms: Description, comprehension, acquisition, and pedagogy. New York/London: Routledge.

Stight, T. G. (1979). Educational uses of metaphor. In A. Ortony (Ed.), Metaphor and thought (2nd ed., pp. 474-485). Cambridge: Cambridge University Press.

Trosborg, A. (1997). Text psychology: Register, genre, text and text type, in-text typology, and translation. John Benjamin.

Wright, J. (1999). Idioms organizer: Organized by metaphor, topic, and key word. UK: Christopher Wenger.

Table 1. Independent Samples $t$ Test for the Juniors

\begin{tabular}{|c|c|c|c|c|c|c|c|}
\hline & $\begin{array}{c}\text { Levine's Test of } \\
\text { Equality of } \\
\text { Variances }\end{array}$ & \multicolumn{6}{|c|}{$t$ Test for Equality of Means } \\
\cline { 2 - 8 } & $F$ & Sig. & $t$ & $d f$ & $\begin{array}{c}\text { Sig. } \\
(2 \text {-tailed })\end{array}$ & $\begin{array}{c}\text { Mean } \\
\text { Differences }\end{array}$ & $\begin{array}{c}\text { Std. Error of } \\
\text { Differences }\end{array}$ \\
\hline $\begin{array}{c}\text { Equal } \\
\text { Variances } \\
\text { Assumed } \\
\text { Equal } \\
\text { Variances } \\
\text { Not Assumed }\end{array}$ & 1.222 & .141 & .922 & 68 & .360 & 2.64375 & 2.86811 \\
\hline
\end{tabular}


Table 2. Tests of Between-Subjects Effects

\begin{tabular}{|c|c|c|c|c|c|}
\hline Source & $\begin{array}{c}\text { Type III Sum of } \\
\text { Squares }\end{array}$ & $d f$ & Mean Square & $F$ & Sig. \\
\hline Intercept & 1088254.72 & 1 & 1088254.72 & 4527.719 & .000 \\
Method & 8787.432 & 1 & 8787.432 & 36.560 & .000 \\
Error & 16344.062 & 68 & 240.354 & & \\
\hline
\end{tabular}

Table 3. Tests of Within-Subjects Contrasts

\begin{tabular}{|c|c|c|c|c|c|}
\hline Source Test & Type III Sum of Squares & $d f$ & Mean Square & $F$ & Sig. \\
\hline $\begin{array}{c}\text { Test Method } \\
\text { Linear }\end{array}$ & 196036.208 & 1 & 196036.208 & 665.267 & .000 \\
\hline $\begin{array}{c}\text { Test Method } \\
\text { Linear }\end{array}$ & 6124.798 & 1 & 6124.798 & 20.785 & .000 \\
\hline $\begin{array}{c}\text { Error (Test) } \\
\text { Linear }\end{array}$ & 20037.77 & 68 & 294.673 & & \\
\hline
\end{tabular}

Table 4. Paired Sample $t$ Test for Group 1

\begin{tabular}{|c|c|c|c|c|c|c|}
\hline \multirow{2}{*}{$\begin{array}{c}\text { Pretest vs. } \\
\text { Posttest } \\
\text { Sections }\end{array}$} & \multicolumn{3}{|c|}{ Paired Differences } & \multirow[b]{2}{*}{$t$} & \multirow[b]{2}{*}{$d f$} & \multirow{2}{*}{$\begin{array}{c}\text { Sig. } \\
\text { (2-tailed) }\end{array}$} \\
\hline & Mean & $\begin{array}{c}\text { Std. } \\
\text { Deviation }\end{array}$ & $\begin{array}{l}\text { Std. Error of } \\
\text { Mean }\end{array}$ & & & \\
\hline $\begin{array}{l}\text { Pretest- } \\
\text { Posttest }\end{array}$ & -88.981258 & 27.02761 & 4.27344 & -20.822 & 39 & .000 \\
\hline
\end{tabular}

Table 5. Paired Sample $t$ Test for Group 2

\begin{tabular}{|c|c|c|c|c|c|c|}
\hline \multirow{2}{*}{$\begin{array}{c}\text { Pretest vs. } \\
\text { Posttest } \\
\text { Sections }\end{array}$} & \multicolumn{3}{|c|}{ Paired Differences } & \multirow[b]{2}{*}{$t$} & \multirow[b]{2}{*}{$d f$} & \multirow{2}{*}{$\begin{array}{c}\text { Sig. } \\
\text { (2-tailed) }\end{array}$} \\
\hline & Mean & Std. Deviation & $\begin{array}{l}\text { Std. Error of } \\
\text { Mean }\end{array}$ & & & \\
\hline $\begin{array}{l}\text { Pretest-Pos } \\
\text { ttest }\end{array}$ & -62.25000 & 19.98825 & 3.64934 & -17.058 & 29 & .000 \\
\hline
\end{tabular}

